\title{
Developing Story Book Based on Local Culture for Improving Prosocial Behaviour
}

\author{
Siti Fadillah \\ Early Childhood Education \\ Universitas Lancang Kuning \\ Pekanbaru, Indonesia \\ sitifadillah@unilak.ac.id
}

\author{
Hapidin \\ Early Childhood Education \\ Universitas Negeri Jakarta \\ Jakarta, Indonesia \\ hapidin1964@gmail.com
}

\author{
Adolf Bastian \\ English Education \\ Universitas Lancang Kuning \\ Pekanbaru, Indonesia \\ adolfbastian@unilak.ac.id
}

\begin{abstract}
The purpose of this research is to develop a storybook based-local culture to improve prosocial behaviour. The method used is research and development with a qualitative and quantitative approach using ASSURE model which consists of analysing learner characteristics, stating objective, selecting media, utilising materials, requiring learners' response, and evaluation. The steps of ASSURE are divided into the preliminary study, development stage, and validation stage. Subjects in this research are children of three kindergartens in the city of Pekanbaru. This research has been through the expert test which shows that the media is possible for field use. Field trial stages begin with one to one trial, small group trials, and large group trials. The result of effectiveness test at large group trial showed that there is a significant difference between the results of the child's prosocial behaviour before and after being given the local story-based storytelling media.
\end{abstract}

Keywords—prosocial behaviour, story books, local culture-based education.

\section{INTRODUCTION}

Prosocial behaviour is one of the social aspects of the emerging and developing in early childhood up to the age or age group 5-6 years B. Prosocial behaviour of children aged 5-6 years are very important in developed as an effort to tackle anti-social behaviour which began shown by the early age children in Indonesia at the moment, such as aggressive behaviour, shows the selfishness (selfish), do not appreciate the work of another, hostile, impatience, and in violation of the applicable rules.

Prosocial behaviour which should develop in early childhood is empathy, can work together, sharing, and measures to help the other people. One way to be able to instil prosocial values in children is education-oriented cultural values. The aim of this culture-based education so that learners can take the value of culture as a guide to behave and as an attempt against the pace of modern culture and foreign culture.

There are some relevant studies that have been done to improve prosocial behaviour as the result of research conducted by Penni Cotton and Nicola Daly [1] with the title of Visualizing Cultures: The " European Picture Book Collection " Moves " Down Under " Children's. The study found that the basic attitude of the children's social will begin to form to indicate the model and the right attitude to them, one way could be presented in picture books based on culture. Research results conducted by Pauline Davey Zeece [2] entitled "Using Current Literature Selections to Nurture the Development of Kindness in Young Child. The study found that children learn the importance of kindness and compassion with others who can encourage the prosocial behaviour of children with the media picture book story of everyday life.

Lisa A. Wright and Rebecca B. McCathren [3] with the title Utilising Social Stories to Increase Prosocial Behaviour and Reduce Problem Behaviour in Young Children with Autism. Our research found that a simple social story very effectively used in improving the prosocial behaviour of autistic children third of the participants read the story of the social.

Based on relevant research and the problems already described above it is necessary to do research on "media development of local culture-based storybook for kindergarten children increase prosocial behaviour Group B in the city of Pekanbaru". Developers expect prosocial behaviour can be improved through the use of media and books can have a positive impact on learning and other developmental aspects.

\section{THEORETICAL STUDIES}

Prosocial behaviour is a behaviour that provides benefits to others, namely sharing (giving goods or stories), helping (doing things to facilitate the second party), showing physical affection so that the second party feels more comfortable and calm, provides support, and cooperates. This means that prosocial behaviour is a behaviour that provides positive benefits for others by showing a willingness to help and care.

Baron and Byrne [4] define prosocial behaviour as any actions taken for the benefit of others or can generally be inferred action in the form of helping others without receiving rewards or replies are felt directly by the people who give aid, although sometimes the behaviour gives a risk to they provide help. Crozier and Tincani [5] suggested that prosocial behaviour is the opposite of anti-social behaviour. Prosocial Behaviour Intervention includes a person at the time of emergency such as charity, collaboration, donate, help, sacrifice and sharing.

Based on some understanding of the above it can be concluded that prosocial behaviour is a form of positive action undertaken by volunteering to provide any assistance or help others without expecting anything in return, and at the time of any circumstances, be able to demonstrate concern for the suffering of others, can cooperate in Completion tasks, and want to share them with anyone. 


\section{A. Picture Story Book}

The storybook is a book-shaped story where there are pictures as representative of related stories. In addition to the pictures in the storybook, there are also writings that represent the story displayed in the picture above. The definition explains that through illustrated storybooks children learn to associate ideas and ideas in books into everyday life that will be a provision for training children's understanding. Mustakim [6] defines a picture book is a book containing a story through a combination of text and illustrations which will determine the definition of form rather than the content. In the children's picture book is told about the child's experience, the world of the family, and social development.

Beltchenko [7] says is a picture book story books instilling the ideas in the story that focuses on the image allowing the child to imagine and understand the purpose of the story. Through picture book, the children will be late in the story, trying to investigate, imagination, and wonder about the meaning of the images in the story books. Bronson [8] stated that the storybook is a unified story that is accompanied by pictures that serve as decorators and supporting stories that can help the process of understanding the contents of the story. This is according to what is written in his book, "Books at various levels of difficulty for children to read story books for reading aloud poetry, rhymes, humorous books, adventure books, myths books made to children". This means that a storybook is a combination of text and images that represent stories that make it easier for children to understand the meaning of a story.

From the above definition can be synthesised that picture book is a book that includes the story which is a combination of text and images. Pictures in books are the main ideas of the story. With the picture is expected to facilitate children in their imagination and understand the meaning of a story written in a book.

\section{B. Local Culture-Based Education}

Tilaar in Panjaitan [9] argues that local culture-based education is education that could not be separated from the educational point of held that culture and society. Teach to their cultural values is also relevant to national development through the provision of education. Jones [10] says that education is essentially a construct of identity. The introduction of local cultural values is an effort in order to establish the identity. This means that through the introduction of local cultural values children will identify cultural values to establish his identity. From the opinions above can be synthesised that education based on local culture is an attempt to establish education life based-society to educate learners and establish the identity or character of learners.

\section{METHOD}

\section{A. Objective}

The objective of this study is to describe the design of a media of local culture based-storybook and see the extent of the effectiveness of instructional media storybook local culture is based on the prosocial behaviour of children in kindergarten group B in the city of Pekanbaru.

\section{B. Types of Research}

Development of local culture-based storybooks to improve prosocial behaviour is a kind of research and development or Research and Development (R\&D). Research and development using the model ASSURE with six stages: (1) Analyse Learners, (2) State Objective, (3) Select Methods, Media and Materials, (4) Utilize Materials, (5) Requires Learner Participation, (6) Evaluate and Revise. The purpose of this research and development is to produce products-based media storybook local culture and test the effectiveness of the product.

\section{Place and Research Time}

Research and development-based media picture books local culture is done in kindergarten group B in the city of Pekanbaru. The study was conducted from April to May 2018.

\section{Population and Sample}

In this development research, the target population for testing small group and large group trials are children kindergarten group B in the city of Pekanbaru is the Village Tuah Karya and Village of Harjosari.

Samples are some of the research objects which represents the population produced by the procedure sampling techniques in accordance with procedures, so sampling was true, representative and accurate so that the results of the study can be generalised. The sampling technique in this developmental research was done by using a multistage stratified cluster random sampling.

\section{E. Steps of Research}

Measures the development of local culture-based storybooks include (1) the preliminary study, (2) planning the development of the model, (3) validation, evaluation, and revision of the media, (4) the implementation of media.

\section{F. Data Collection Instrument}

Data collection instruments consisted of (1) observation, (2) test, (3) interview, (4) documentation, and (5) the questionnaire, namely assessments, advice and input from experts.

\section{G. Data Analysis}

Data analysis performed in this study is in two ways analysis of qualitative data and quantitative data analysis.

\section{H. Qualitative Data Analysis}

Qualitative data analysis is to analyse the data obtained in the process of learning by using media-based storybook local culture which includes the initial observation, interviews, field notes documentation. Qualitative data analysis was conducted to see the effectivity of media use good story books in the learning activities of both teachers and children.

\section{Quantitative Data Analysis}


Quantitative data are obtained from test scores of children in learning activities that use media storybooks based on the local culture. Data from the test results were analysed by comparing pre-test and values post-test of children. This test is done to see if there is a significant difference in the value of the prosocial behaviour of children before and after the use of media-based storybook this local culture. In this case, the statistical calculations done by formula t-test or paired-t-test.

\section{RESULT AND DISCUSSION}

\section{A. Result of Research and Development}

The results of the research and development are the drafting of a local culture-based storybook for early childhood at the TK Group B with the first step of a preliminary study. This preliminary study is divided into two stages: a needs analysis with an observation on early childhood institutions and media needs analysis. The second step is the design of a product consisting of 1) the manufacture of themes and characters, 2) creation of a storyboard/storyline, 3) creation of illustration, 5) preparation of picture books, 6) design validation and 7) design revisions. In the validation phase, based on local culture storybook media was assessed by an expert, linguist, an expert in early childhood, and the custom expert. The third step is a trial to determine the effectiveness of mediabased storybook local culture in promoting prosocial behaviour. Tests conducted by the trial one to one, piloting a small group, and large group trial involving the three kindergartens group B in the city of Pekanbaru.

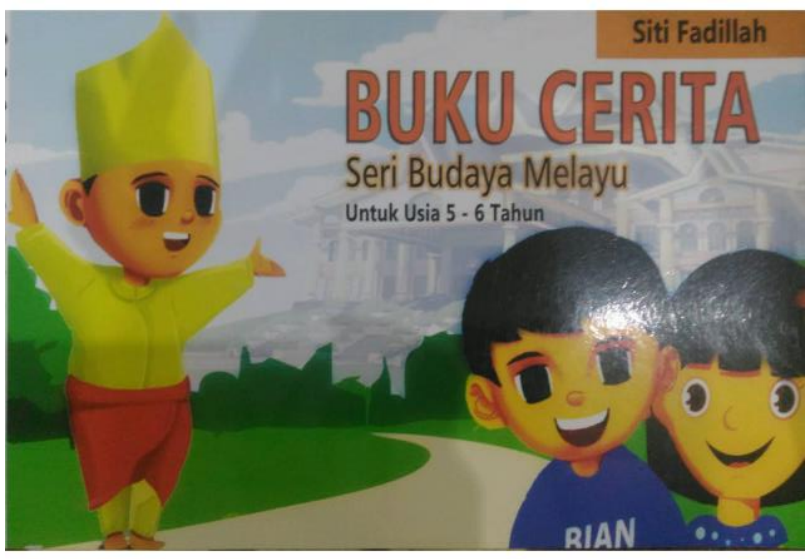

Fig 1. Cover of The Storybook

\section{B. Discussions}

These research and development were carried out in kindergarten group B in the city of Pekanbaru. The research was conducted on three schools namely TK Mayang, TK Mayerd Kids, and TK Aisyiyah Pekanbaru. The results of the effectiveness test on small group trials in TK Mayang which was calculated by paired-t-test obtained t-count of 11.404 and t-table 2.179 , $t$-count $>$ from $\mathrm{t}$-table so that there is a significant difference or Ho is rejected. Furthermore, the results of the effectiveness test in large group trials at Mayerd Kids Kindergarten obtained the results of t-count 14.379 and t-table 2.145 or $\mathrm{t}$-count $>$ from t-able, so that there is a significant difference or Ho is rejected. The results of the effectiveness test in large group trials conducted in TK Aisyiyah Pekanbaru obtained the results of t-count 13.081 and t-table 2.132 or $\mathrm{t}$-count $>\mathrm{t}$-table, there is a significant difference or Ho is rejected. From the results of the effectiveness test in the three kindergarten groups B in Pekanbaru, it can be concluded that there are differences between the results of the prosocial behaviour of children before and after being given the media of storybooks based on local culture. In other words, the use of media books based on local culture can influence the prosocial behaviour of children in the Pekanbaru B kindergarten group.

Based on data from interviews and court records obtained results reinforce the appropriateness or effectiveness of the media developed storybook. From interviews and field notes were worth the conclusion that the media use in learning because received a positive response of learners, learners are very interested and able to understand the material content of the story told by the teacher.

Results of research and development-based media storybook local culture is not only effective increase prosocial behaviour of children, yet effective in improving other aspects of development such as language, psychology, and understanding of the culture.

\section{CONCLUSION AND RECOMMENDATION}

\section{A. Conclusion}

Media developed this storybook is an alternative media that can be used to overcome the problem of prosocial behaviour is still often found in early childhood institutions, especially at the kindergarten group $\mathrm{B}$ in the city of Pekanbaru. Pursuant to the results of testing the viability of the media users conducted at three places, namely, TK Mayang, Mayerd Kids kindergarten, and kindergarten Aisyiyah Pekanbaru result or conclusion that the media already developed proven to effectively improve the behaviour of children prosocial. The increase was seen from the results of the initial assessment and final showed a significant difference before and after the use of mediabased storybook local culture. From the results noted the field and interviews with teachers visible results that will strengthen media feasibility of local culture-based storybook that has been developed. Results of interviews with teachers prove that the media storybook developed based on local culture has never existed, teachers assess that the media developed a very attractive and feasible for early childhood. In addition to media interviews, measured feasibility of the results of field notes research activities, where children seen interest in listening to stories read.

\section{B. Recommendation}

Based on the conclusions described above, the researchers tried to give suggestions - suggestions as follows:

1) Educators or teachers of that age could provide a creative learning and fun. A teacher should have to be more active in new innovations to make learning media such as the media-based storybook local culture that has 
developed. It is useful to assist teachers in delivering learning, especially for improving children' prosocial behaviour.

2) Research and development of storybook local culturebased were produce books with themes of Riau Malay community culture, but this developed storybook just raised four local cultural themes Riau Malay community. Therefore, it is expected that the academics who become partners for educators to develop or carry out a similar study relating to this topic with the theme of the other Riau Malay community culture or local culture of other regions in Indonesia.

\section{REFERENCES}

[1] Penni Cotton • Nicola Daly, Visualising Cultures: The "European Picture Book Collection" Moves "Down Under"Children's, Literature in Education DOI 10.1007/s10583-014-9228-9 (Springer Science Business Media New York 2014 (diakses tanggal 18 Oktober 2016)

[2] P. D. Zeece, "Using current literature selections to nurture the development of kindness in young children.", Early Childhood Education Journal 36.5, 2009, p. 447-452.

[3] Lisa A.Wright and Rebecca B.McCathren, Utilizing Social Stories to Increase Prosocial Behaviour and Reduce Problem Behaviour in
Young Children with Autism, Child Development Research Volume 2012, Article ID 357291, 13 pages doi:10.1155/2012/357291

[4] Baron, Robert A., and Donn Erwin Byrne. Social psychology: Understanding human interaction. Allyn \& Bacon, 1984.

[5] S. Crozier, and M. Tincani, Effects of social stories on prosocial behavior of preschool children with autism spectrum disorders, Journal of autism and developmental disorders 37.9, 2007, p. $1803-1814$

[6] M. N. Mustakim, Peranan Cerita Dalam Pembentukan Perkembangan Anak TK, Jakarta: Departemen Pendidikan Nasional, 2005.

[7] L. Beltchenko, Intellectual Pursuits of Young Children Through Picture Book Literacy, Focusing on Italian Preschools, Gifted Child Today 39.3, 2016, p. 145-153.

[8] M. B. Bronson, The Raight Stuff for Children Birth to 8, Washington DC:NAEYC, 1995.

[9] A. P. Panjaitan, A. Darmawan, I. R. Purba, Y. Rachmad, R. Simanjuntak, Korelasi Kebudayaan dan Pendidikan: Membangun Pendidikan Berbasis Budaya Lokal, Jakarta: Yayasan Pustaka Obor Indonesia, 2014.

[10] S. R. Jones, Intersectionality in educational research, Stylus Publishing, LLC, 2015. 